\title{
The diagnosis of delayed post-operative endophthalmitis by polymerase chain reaction of bacterial DNA in vitreous samples
}

\author{
P. G. HYKIN, K. TOBAL, G. McINTYRE*, M. M. MATHESON†, H. M. A. TOWLER and \\ S. L. LIGHTMAN
}

Departments of Clinical Science and $\uparrow$ Pathology, Institute of Ophthalmology, Bath Street, London EC1V 9EL and

* Department of Medical Microbiology, University College London Medical School, London W1P 7PN

\begin{abstract}
Summary. Delayed post-operative endophthalmitis is a complication of modern cataract extraction and posterior chamber lens implantation. Propionibacterium acnes has been isolated in a few such cases but the majority are culture-negative, compounding surgical and medical management decisions. A method of detecting bacterial, and specifically P. acnes, DNA by the polymerase chain reaction (PCR) directed at 16S rDNA is reported. Nested PCR with universal eubacterial primers complimentary to regions of 16S rDNA conserved sequences detected $50 \mathrm{fg}$ of bacterial DNA spike in normal vitreous. Nested PCR with $P$. acnes primers detected $10 \mathrm{fg}$ of DNA. Vitreous samples from 29 patients undergoing vitrectomy for reasons unrelated to infection and 23 samples from 19 patients with delayed post-operative endophthalmitis were analysed. Four (14\%) of 29 normal individuals and 17 (74\%) of 23 delayed cases gave positive results with universal eubacterial primers. None of 29 and eight of 23 samples gave positive results with $P$. acnes primers. The $14 \%$ positive rate with universal primers in non-infected cases may limit their use in delayed post-operative endophthalmitis. PCR detection of bacterial DNA with specific primers from vitreous samples may prove a useful means of diagnosing delayed post-operative endophthalmitis and facilitating management decisions when conventional bacterial culture is negative.
\end{abstract}

\section{Introduction}

Intra-ocular infections after ophthalmic surgery are fortunately very rare. ${ }^{1}$ Acute post-operative endophthalmitis is a well characterised and severe complication of intra-ocular surgery, most frequently due to Staphylococcus epidermidis, S. aureus, Streptococcus spp., and gram-negative organisms. ${ }^{2-6}$ The clinical course is rapidly progressive and the prognosis generally poor, despite aggressive surgical and antibiotic therapy. ${ }^{7,8}$ The occurrence of delayed post-operative endophthalmitis has been recognised increasingly in recent years and typically follows extracapsular cataract extraction with posterior chamber lens implantation..$^{9-16}$ It occurs $1-11$ months after surgery, is characterised by repeated episodes of low grade inflammation - which in the early stages may respond to topical steroid treatment-and clinically by large keratoprecipitates, hypopyon, white plaques on the posterior capsule, a capsular abscess and anterior vitritis. ${ }^{11-13,15-17}$ Although Propionibacterium acnes ${ }^{9-16}$ and P. granulosum, ${ }^{17,18}$ P. propionicus (Arachnia propionica $),{ }^{17}$ S. epidermidis, ${ }^{17,19,20}$ Actinomyces israelii, ${ }^{21}$

Received 1 Sept. 1993; accepted 9 Dec. 1993
A. viscosus ${ }^{21}$ and Corynebacterium $\mathrm{sp}^{22}$ have been reported in such cases, the majority are culturenegative. Reasons for this include small numbers of causative organisms present within the eye, the possible localised nature of the infection leading to sampling error and the fastidious growth requirements of Propionibacterium spp. This results in a clinical dilemma in which post-operative inflammation due to phaco-anaphylactic uveitis, idiopathic post-operative inflammation or delayed post-operative endophthalmitis $^{23}$ cannot be distinguished easily. Decisions regarding the appropriate form and timing of surgical intervention and the use of systemic and topical steroids and antibiotics become difficult. ${ }^{10,11,16,17}$ To minimise these problems, a method of detecting bacterial DNA in vitreous samples is described based on the polymerase chain reaction (PCR) amplification of bacterial $16 \mathrm{~S} \mathrm{rDNA} .{ }^{24}$ It has potential advantages in that only a very small sample is required for analysis, minute numbers of bacteria can be detected and conventional microbial culture is not required. ${ }^{25}$ In this study, universal eubacterial primers ${ }^{26}$ from regions of conserved sequence were employed to determine whether a vitreous sample contained bacterial DNA, and primers specific to $P$. acnes, in the context of delayed post-operative endophthalmitis, were used to 
Table I. NCTC and identification strains of bacteria responsible for acute and delayed post-operative endophthalmitis

\begin{tabular}{|c|c|c|c|c|}
\hline$P$. acnes strains & $\begin{array}{l}\text { Delayed post-operative } \\
\text { endophthalmitis }\end{array}$ & $\begin{array}{l}\text { NCTC } \\
\text { no. }\end{array}$ & $\begin{array}{l}\text { Acute post-operative } \\
\text { endophthalmitis }\end{array}$ & $\begin{array}{l}\text { NCTC } \\
\text { no. }\end{array}$ \\
\hline \multicolumn{5}{|l|}{ NCTC 737} \\
\hline $\begin{array}{l}\text { Identification } \\
\text { strains: }\end{array}$ & S. epidermidis & 11407 & S. aureus & 8532 \\
\hline $\mathrm{A} 160 / 87$ & P. granulosum & 11865 & Str. pyogenes & 8198 \\
\hline A234/85 & P. propionicus & 11666 & Str. pneumoniae & 7465 \\
\hline A155/85 & A. israelii & 10236 & Str. sanguis & 7863 \\
\hline A5/87 & A. viscosus & 10951 & Serratia marcescens & 10211 \\
\hline A58/87 & C.xerosis & 7238 & Ps. aeruginosa & 10322 \\
\hline A195/87 & C. pseudodiphtheriae & 11136 & Pr. mirabalis & 660 \\
\hline A222/87 & & & Bacillus cereus & 2599 \\
\hline A245/87 & & & Haemophilus influenzae & 8143 \\
\hline A253/87 & & & Klebsiella pneumoniae & 9633 \\
\hline A123/89 & & & Enterococcus faecalis & 775 \\
\hline
\end{tabular}

detect the presence of this organism in vitreous samples.

\section{Materials and methods}

\section{Clinical samples}

Vitreous samples were obtained from 29 control patients undergoing three-port pars plana vitrectomy. The indications for surgery included retinal detachment and vitreous haemorrhage; in no case was infective endophthalmitis suspected. Twenty-three vitreous samples were obtained from 19 patients with delayed post-operative endophthalmitis. Samples were obtained under sterile operating conditions either by passing a needle attached to a 2 -ml syringe through the pars plana of the eye, or by passing a needle through a pre-existing pars plana vitrectomy port at the commencement of the vitrectomy procedure, slowly withdrawing $250 \mu \mathrm{l}$ of vitreous, placing $100 \mu \mathrm{l}$ in a presterilised microfuge tube for PCR, and using $150 \mu \mathrm{l}$ for conventional microbiological analysis.

\section{Gram's stain and culture}

Gram's stain was performed on representative smears from all infected cases. Clinical specimens, infected and non-infected, were cultured at $37^{\circ} \mathrm{C}$ on blood agar, incubated aerobically and anaerobically, chocolate agar incubated in air with $\mathrm{CO}_{2} 5 \%$ and in Robertson's cooked meat broth. Liquid phase cultures were subcultured at $48 \mathrm{~h}$ on to blood agar for aerobic and anaerobic incubation; anaerobic cultures were maintained for 7 days.

\section{DNA extraction}

Vitreous $(50 \mu \mathrm{l})$ was added to $150 \mu \mathrm{l}$ of suspension buffer (10 mM Tris- $\mathrm{HCl}, \mathrm{pH} 8 \cdot 3,2.5 \mathrm{mM} \mathrm{MgCl}, 50 \mathrm{~mm}$ $\mathrm{KCl}$ ), phenol $200 \mu \mathrm{l}, 20 \mu \mathrm{l}$ of SDS $20 \%$ and $100 \mu \mathrm{l}$ of $100-\mu \mathrm{m}$ diameter glass beads and agitated for $2 \mathrm{~min}$ in

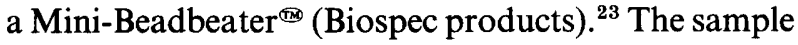

was centrifuged for $1 \mathrm{~min}$ at $15600 \mathrm{~g}$ and the aqueous phase was removed, from which DNA was precipitated with ethanol (2 volumes) and $3 \mathrm{M}$ sodium acetate, pH 5.2 ( $0 \cdot 1$ volumes), washed with ethanol $70 \%$, dried in a vacuum dessicator and reconstituted in $10 \mu \mathrm{l}$ of TE buffer; $5 \mu$ l were added to the PCR reaction.

DNA was extracted from NCTC (National Collection of Type Cultures, 61 Colindale Avenue, London) and identification strain organisms (table I) by suspending the bacteria in $400 \mu \mathrm{l}$ of TEST buffer (10 mm Tris-HCl, pH 8.0, $5 \mathrm{~mm}$ EDTA, pH 8.0, $1 \mathrm{~mm}$ $\mathrm{NaCl}$, Triton X100 0.5\%); lysozyme was added to a final concentration of $2 \mathrm{mg} / \mathrm{ml}$ and the suspension was incubated at $37^{\circ} \mathrm{C}$ for $2 \mathrm{~h}$, followed by the addition of proteinase $\mathrm{K}(20 \mathrm{mg} / \mathrm{ml}) 8 \mu \mathrm{l}$ and $40 \mu \mathrm{l}$ of $\mathrm{N}$-lauryl sarcosine (sarkosyl) and incubation at $37^{\circ} \mathrm{C}$ for $1 \mathrm{~h}$. An equal volume of phenol: chloroform: isoamyl alcohol was added and centrifuged at $15600 \mathrm{~g}$ for $2 \mathrm{~min}$; the aqueous phase was removed ${ }^{27}$ and nucleic acids were precipitated with ethanol ( 2 volumes) and $3 \mathrm{M}$ sodium acetate, $\mathrm{pH} 5 \cdot 2$ ( 0.1 volumes), and redissolved in $10 \mu \mathrm{l}$ TE buffer. The DNA concentration was adjusted to $5 \mathrm{ng} / \mu \mathrm{l} ; 2 \mu \mathrm{l}$ of sample $(10 \mathrm{ng})$ were added to the PCR reaction.

\section{Oligonucleotide primer design}

Universal eubacterial oligonucleotide primers. Highly conserved regions of $16 \mathrm{~S}$ rDNA were identified ${ }^{24,28,29}$ and primers (U1 and rU4) and (U2 and rU3) (table II) were synthesised (394 Synthesiser) and purified by HPLC (Oswells) to generate a 766-bp (round 1) and a 470-bp (round 2) product. The primers had broad specificity for gram-positive and -negative bacteria known to cause infective endophthalmitis (table II).

$P$. acnes oligonucleotide primers. Multiple alignment $^{30}$ of $16 \mathrm{~S}$ rDNA sequences of $P$. acnes, $P$. propionicus, $A$. israeli, $A$. viscosus and $C$. xerosis identified areas of low sequence homology, which included previously characterised variable regions $\mathrm{V} 1$, $\mathrm{V} 2$ and $\mathrm{V} 3{ }^{27} \mathrm{~S}$. epidermidis $16 \mathrm{~S}$ rDNA sequence information was unavailable. Primer Pa1 was synthe- 
Table II. Universal eubacterial and $P$. acnes-specific oligodeoxynucleotide primers

\begin{tabular}{llc}
\hline Primer & \multicolumn{1}{c}{$\begin{array}{c}\text { Sequence } \\
\left(5^{\prime}-3^{\prime}\right)\end{array}$} & $\begin{array}{c}\text { Position in } \\
E . \text { coli } \\
16 \mathrm{~S} \text { rDNA }\end{array}$ \\
\hline U1 & TTGGAGAGTTTGATCCTGGCTC & $4-25$ \\
U2 & GGCGTGCTTAACACATGCAAGTCG & $41-64$ \\
rU3 & GCGGCTGGCACGTAGTTAG & $506-528$ \\
rU4 & GGACTACCAGGGTATCTAA & $789-806$ \\
Pa1 & AAGGCCCTGCTTTTGTGG & $71-88$ \\
rPa2 & TCCATCCGCAACCGCCGAA & $199-216$ \\
rPa3 & ACTCACGCTTCGTCACAG & $442-459$ \\
\hline
\end{tabular}

sised from $P$. acnes region $\mathrm{V} 1, \mathrm{rPa} 2$ from region $\mathrm{V} 2$ and $\mathrm{rPa} 3$ from region $\mathrm{V} 3$ (table II). $\mathrm{Pa} 1$ and $\mathrm{rPa} 3$ gave a 387-bp product, and $\mathrm{Pa} 1$ and $\mathrm{rPa} 2$ a 160 -bp product. These $P$. acnes primers did not amplify DNA from other causative organisms of delayed post-operative and acute endophthalmitis (table III) except $A$. israelii, an extremely rare cause of delayed post-operative endophthalmitis. The 160 -bp product of these two organisms has a base-pair difference (Escherichia coli position 93), contained in the recognition site of restriction endonuclease $\mathrm{XhoI}$, which was employed to differentiate them.

\section{Prevention of contamination}

Sample agitation and PCR preparation were performed in one laboratory, clinical sample addition in a second laboratory and PCR was performed and products analysed in a third laboratory. PCR preparation was performed in a laminar flow cabinet with single-use aliquots of each reagent, dedicated pipettes and plugged tips. Microfuge tubes and mineral oil aliquots were double autoclaved before use. Each universal eubacterial sample was treated with 1 unit of DNAase 1 (Boehringer) at $37^{\circ} \mathrm{C}$ followed by $10 \mathrm{~min}$ at $85^{\circ} \mathrm{C}$ before addition of primer, to remove inherent bacterial contamination of Taq DNA polymerase. ${ }^{31}$ Before the addition of template, samples were exposed to short wave UV light for $10 \mathrm{~min}$.

\section{PCR optimisation}

Universal eubacterial oligonucleotide primers. A 50- $\mu \mathrm{l}$ reaction was optimised with 1 unit of Taq DNA polymerase (Stratagene), $200 \mu \mathrm{m}$ of each deoxynucleotide triphosphate, $5 \mu \mathrm{l}$ of $\times 10$ buffer $(500 \mathrm{mM} \mathrm{KCl}$, $100 \mathrm{~mm}$ Tris-Cl, $15 \mathrm{mM} \mathrm{MgCl}_{2}$, gelatin $0.1 \%, \mathrm{pH} 8 \cdot 3$ ), $0.36 \mu \mathrm{m}$ of each primer, $5 \mu \mathrm{l}$ of template $(10 \mathrm{ng}$ of DNA, $c .10^{6}$ genome copies) and water was added to $50 \mu \mathrm{l}$. The reaction was overlayed with $50 \mu \mathrm{l}$ of mineral oil and performed in a Quattro TC 140 thermocycler. The reaction was heated for the first cycle to $94^{\circ} \mathrm{C}$ for $5 \mathrm{~min}$, annealing was performed at $60^{\circ} \mathrm{C}$ (round 1), and $58^{\circ} \mathrm{C}$ (round 2), for $1 \mathrm{~min}$ and extension at $72^{\circ} \mathrm{C}$ for 2 min. Subsequent cycles, 34 (round 1) and 24 round 2), consisted of $94^{\circ} \mathrm{C}$ for $30 \mathrm{~s}, 60^{\circ} \mathrm{C}$ (round 1), $58^{\circ} \mathrm{C}$ (round 2), for $1 \mathrm{~min}$ and $72^{\circ} \mathrm{C}$ for $2 \mathrm{~min}$, with a final extension at $72^{\circ} \mathrm{C}$ for $8 \mathrm{~min}$.

$P$. acnes oligonucleotide primers. $\mathrm{Pa} 1, \mathrm{rPa} 2$ and $\mathrm{rPa} 3$ primer concentration was $1 \mu \mathrm{M}, 2$ units of Taq DNA polymerase were added and the temperature profile was $94^{\circ} \mathrm{C}$ for $5 \mathrm{~min}, 62^{\circ} \mathrm{C}$ (rounds 1 and 2), for $1 \mathrm{~min}$ and $72^{\circ} \mathrm{C}$ for $2 \mathrm{~min}$. There were 34 (round 1) and 24 (round 2) subsequent cycles consisting of $94^{\circ} \mathrm{C}$ for $30 \mathrm{~s}, 62^{\circ} \mathrm{C}$ (rounds 1 and 2) for $1 \mathrm{~min}$ and $72^{\circ} \mathrm{C}$ for $2 \mathrm{~min}$, with a final extension at $72^{\circ} \mathrm{C}$ for $8 \mathrm{~min}$.

\section{PCR specificity}

Universal eubacterial oligonucleotide primers were employed to amplify $16 \mathrm{~S}$ rDNA from all principal organisms known to cause acute and delayed postoperative endophthalmitis (table I). $P$. acnes oligonucleotide primers were employed to amplify $P$. acnes DNA from NCTC strain 737, from $11 P$. acnes identification strains and from organisms known to cause acute and delayed post-operative endophthalmitis. PCR was performed with all primer combinations versus human nuclear DNA to ensure no cross reactivity.

\section{PCR sensitivity}

Ten-fold serial dilutions of DNA extracted from $S$. epidermidis in water and non-infected vitreous and of DNA extracted from serial dilutions of organisms suspended in phosphate-buffered saline were amplified with universal primers $\mathrm{U} 1$ and $\mathrm{rU} 4$, and $\mathrm{U} 2$ and $\mathrm{rU} 3$. One $\mu \mathrm{l}$ of the first round was used in the second round of amplification. Ten-fold dilutions of $P$. acnes DNA in water and in normal vitreous were amplified with $\mathrm{Pa} 1$ and $\mathrm{rPa}$, and $\mathrm{Pa} 1$ and $\mathrm{rPa}$. The sensitivity of each PCR procedure was assessed after the first and second rounds of amplification.

\section{$P C R$ analysis of clinical specimens}

Five $\mu \mathrm{l}$ of DNA from each clinical sample were added directly to the PCR reaction. Each clinical specimen was amplified in the presence of negative controls, for the sample agitation and the PCR steps, and positive controls $(5 \mathrm{pg}$ and $50 \mathrm{fg}$ of $P$. acnes DNA). A negative result was confirmed by spiking the clinical specimen with $P$. acnes DNA, and repeating the PCR to exclude the possibility of a false-negative result due to the presence of PCR inhibitors in the vitreous sample. The PCR products were separated by electrophoresis in agarose $1.5 \%$ gel containing ethidium bromide $0.5 \mu \mathrm{g} / \mathrm{ml}$ and visualised with a transilluminator at $302 \mathrm{~nm}$.

\section{XhoI restriction endonuclease digest}

The 160-bp DNA PCR products of $P$. acnes and $A$. israeli were distinguished by incubation at $37^{\circ} \mathrm{C}$ in the presence of 10 units of $\mathrm{XhoI}$ (Pharmacia) and endo- 
Table III. Primers $\mathrm{Pa} 1, \mathrm{rPa} 2, \mathrm{rPa} 3$ with complimentary, $16 \mathrm{~S}$ rDNA sequences from species known to cause delayed and acute post-operative endophthalmitis

\begin{tabular}{|c|c|c|c|}
\hline Bacterial species & $\begin{array}{ccc}5^{\prime} & \text { Pal } & 3^{\prime} \\
\text { AAGGCCCTGCTTTTGTGG }\end{array}$ & $\begin{array}{ccc}5^{\prime} & \mathrm{rPa} 2 & 3^{\prime} \\
\text { TCCATCCCCAACCGCCGAA }\end{array}$ & $\begin{array}{ccc}5^{\prime} & \mathrm{rPa} 3 & 3^{\prime} \\
\text { ACTCACGCTTCGTCACAG }\end{array}$ \\
\hline $\begin{array}{l}\text { Delayed endophthalmitis } \\
\text { A. israelii } \\
\text { P. propionicus } \\
\text { A. viscosus } \\
\text { C. xerosis } \\
\text { Acute endophthalmitis } \\
\text { Str. pneumoniae } \\
\text { Str. sanguis } \\
\text { Str. pyogenes } \\
\text { Ps. aeruginosa } \\
\text { Citrobacter freundii } \\
\text { H. influenzae } \\
\text { Ser. marcescens }\end{array}$ & $\begin{array}{l}\text { NA } \\
\text { AAGGCCC--T-TCG } \\
\text { GGGAGCCAGCTXXXXXX } \\
\text { AAGGCCCAGCTTGC-TGG } \\
\text { NA } \\
\text { NGA } \\
\text { NGAGCTTGC--CT-TGG } \\
\text { GGGAGCTTGC--CT-TGG } \\
\text { AGGAGCTTGCTCCT-TGG } \\
\text { GAAAGCTTGCTTTC-TTG } \\
\text { GGGAGCTTGCTCCC-TGG }\end{array}$ & $\begin{array}{l}\text { XCXATCCCCAACCGCCGAA } \\
\text { TCCATCCCACACCGCAAAA } \\
\text { CCXATCCCCCACCGGAXCT } \\
\text { TCCATCCCACACCG-AAAA } \\
\text { TCCATCTGGTAGTGATGCA } \\
\text { TCCATCTGGCAGTGATGCX } \\
\text { TCCATCTCATAGTGXAGCA } \\
\text { CTCATCTGATAGCG-TGAG } \\
\text { CACATXXGATGGCA-AGAG } \\
\text { CTCATCCTATGGCA-TGCG } \\
\text { CACATCTGATGGCA-AGAG }\end{array}$ & $\begin{array}{l}\text { ACTCACGCTTCGTCACAG } \\
\text { ACTTGCGCTTCGTCCCTA } \\
\text { ACCXA*C*GCCT*CTTCACAT*G } \\
\text { AGAAAACCTTCGTCGATGG } \\
\text { A*CTCACACTC*TTCTTCTCTT } \\
\text { A*CTCACACCC }{ }^{*} \text { TTCTTCTCTT } \\
\text { A*CCCACCATCATTCTTCTCTA } \\
\text { A*TTACTGCCCTTCCTCCCAA } \\
\text { A*CTCAACXCCTTCCTCCTCG } \\
\text { A*ACATCAACCTTCCTCAATA } \\
\text { A*CTCACCACCTTCCTCCTCG }\end{array}$ \\
\hline
\end{tabular}

NA, not available; $\mathrm{X}$, indeterminate base; -, base deletion; ${ }^{*}$, base insertion (number and type not shown).

nuclease digest buffer (10 mM Tris acetate, $\mathrm{pH} 7 \cdot 5$, $10 \mathrm{~mm} \mathrm{Mg}$ acetate, $50 \mathrm{~mm} \mathrm{~K}$ acetate). The products were analysed by electrophoresis in polyacrylamide $6 \%$ gels containing ethidium bromide $0.5 \mu \mathrm{g} / \mathrm{ml}$.

\section{Results}

\section{PCR specificity}

Universal primers, U1 and rU4, and U2 and rU3 amplified successfully DNA from all recognised pathogens in acute and delayed post-operative endophthalmitis to give $c$. 766-bp and $c$. 470-bp fragments. Human nuclear DNA was not amplified. $P$. acnes primers $\mathrm{Pa} 1$ and $\mathrm{rPa} 3$, and $\mathrm{Pa} 1$ and $\mathrm{rPa} 2$ amplified DNA from all 11 strains of $P$. acnes and $A$. israelii. DNA from other organisms known to cause delayed and acute post-operative endophthalmitis was not amplified (figs. 1 and 2). Weak amplification of $A$. viscosus DNA occurred with $\mathrm{Pa} 1$ and $\mathrm{rPa} 2$ at an annealing temperature of $58^{\circ} \mathrm{C}$ but not at $62^{\circ} \mathrm{C}$.

\section{$P C R$ sensitivity}

After prior DNAase 1 treatment, DNA amplification with U1 and rU4 for 35 cycles permitted detection of $1 \mathrm{pg}$ of $S$. epidermidis DNA in TE buffer and in normal vitreous. With nested PCR (U2 and rU3) for a further 25 cycles, $50 \mathrm{fg}$ of $S$. epidermidis DNA in TE buffer and in normal vitreous was detected. Without prior DNAase 1 treatment, DNA amplification with $\mathrm{Pa} 1$ and $\mathrm{rPa} 3$ for 35 cycles per-

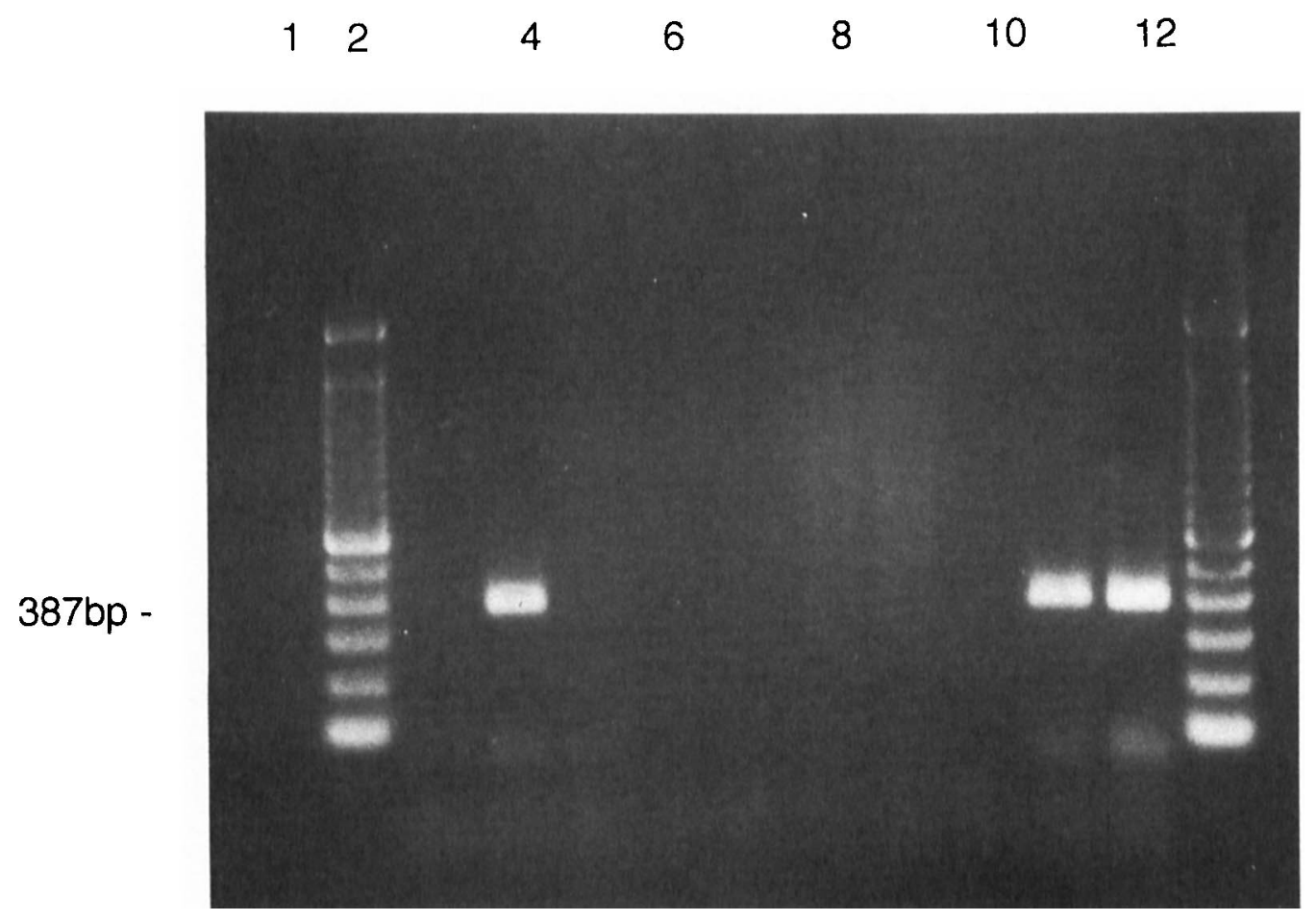

Fig. 1. Nested PCR results with Pa1, rPa3. Lane 1, negative control; 2 and 13, 100-bp mol. wt marker; 3, S. epidermidis; 4, P. acnes;

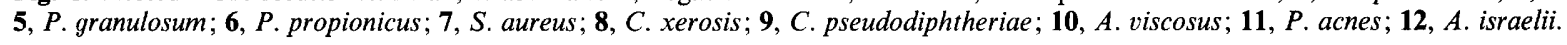




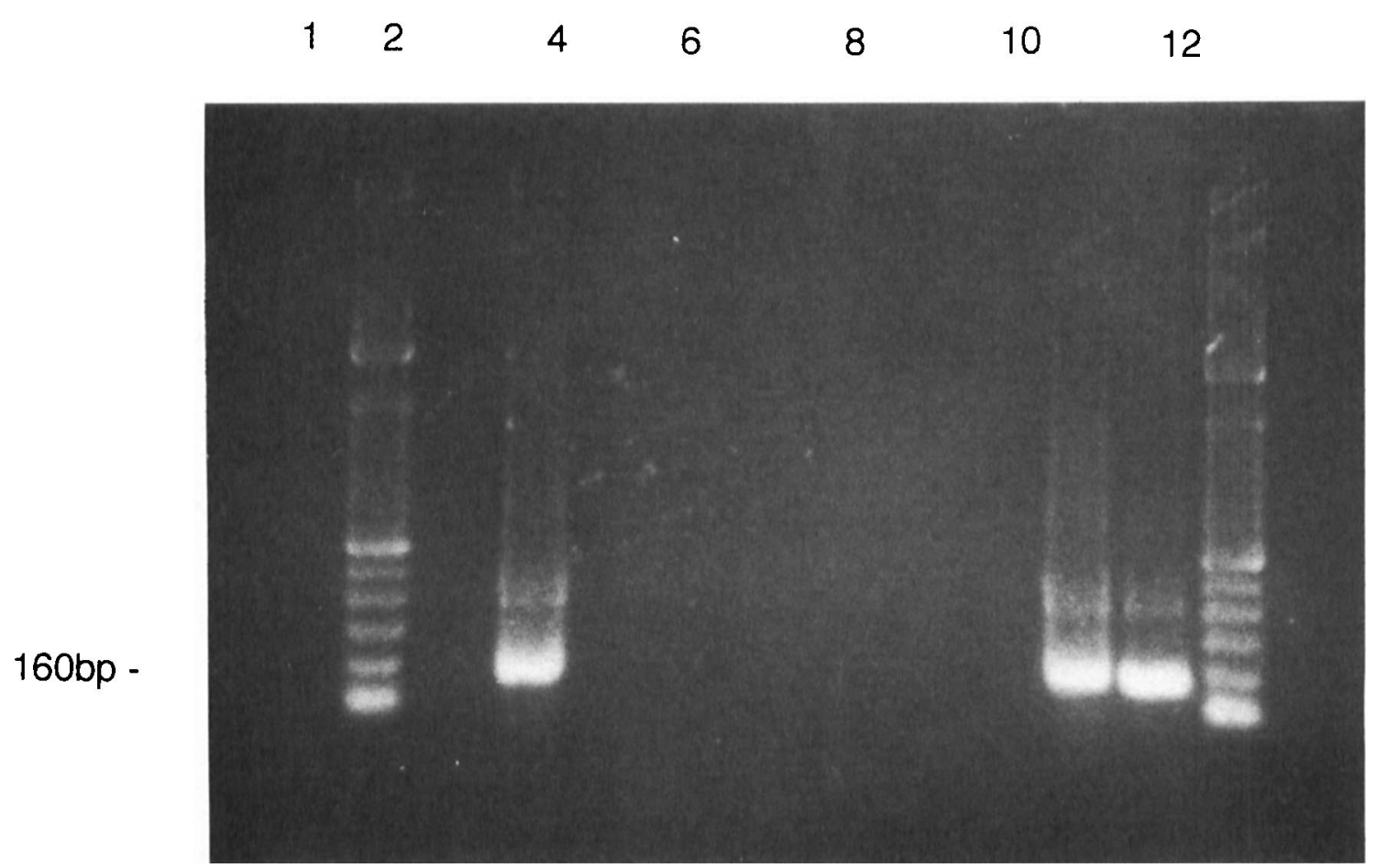

Fig. 2. Nested PCR results with Pal, rPa2. Lane 1, negative control; 2 and 13, 100-bp mol. wt marker; 3, S. epidermidis; 4, P. acnes;

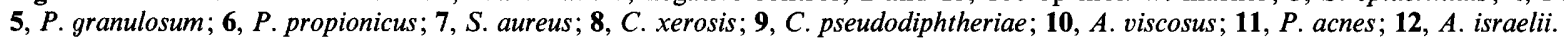

Table IV. Gram's stain, vitreous culture and PCR results from 19 patients presenting with a clinical diagnosis of delayed pseudophakic endophthalmitis

\begin{tabular}{|c|c|c|c|c|c|c|c|c|}
\hline \multirow{2}{*}{$\begin{array}{l}\text { Patient } \\
\text { no. }\end{array}$} & \multirow{2}{*}{$\begin{array}{l}\text { Eye } \\
R / L\end{array}$} & \multirow{2}{*}{$\begin{array}{l}\text { Procedure at } \\
\text { diagnosis }\end{array}$} & \multirow{2}{*}{ Gram's stain } & \multirow{2}{*}{ Vitreous culture } & \multicolumn{4}{|c|}{ PCR results } \\
\hline & & & & & EUP & IUP & EPAP & IPAP \\
\hline 1 & $\mathbf{L}$ & Capsule biopsy & $\begin{array}{l}\text { Pleomorphic } \\
\text { positive rods }\end{array}$ & P. acnes & + & + & + & + \\
\hline 1 & $\mathbf{L}$ & Capsule biopsy & $\begin{array}{l}\text { Pleomorphic } \\
\text { positive rods }\end{array}$ & P. acnes & + & + & + & + \\
\hline 2 & L & Vitrectomy & Negative & Citrobacter freundii & + & + & _- & - \\
\hline 3 & $\mathbf{R}$ & Vitrectomy & Negative & Negative & + & + & - & - \\
\hline 4 & $\mathbf{R}$ & Vitrectomy & Negative & Negative & + & + & - & - \\
\hline 5 & $\mathrm{~L}$ & Vitrectomy & Negative & Negative & - & - & - & - \\
\hline 6 & $\overline{\mathrm{L}}$ & Vitrectomy & Negative & Negative & + & + & - & - \\
\hline 7 & $\mathrm{~L}$ & Vitrectomy & Negative & Negative & - & - & - & - \\
\hline 8 & $\mathrm{R}$ & Vitrectomy & Negative & Negative & - & - & - & - \\
\hline 9 & $\mathbf{R}$ & Vitrectomy & Negative & $\begin{array}{l}\text { Streptococcus } \\
\text { Group D }\end{array}$ & + & + & - & - \\
\hline 10 & $\mathbf{R}$ & Vitreous biopsy & Negative & Negative & - & - & - & - \\
\hline 11 & $\mathrm{R}$ & Vitrectomy & Negative & S. epidermidis & + & + & - & - \\
\hline 12 & $\mathrm{~L}$ & Vitrectomy & Negative & Negative & - & - & - & - \\
\hline 13 & $\bar{L}$ & Vitreous biopsy & Positive cocci & $\begin{array}{l}\text { S. epidermidis } \\
\text { S. aureus }\end{array}$ & + & + & - & - \\
\hline 14 & $\mathbf{R}$ & Vitreous biopsy & Positive cocci & S. epidermidis & + & + & + & + \\
\hline 15 & $\mathrm{~L}$ & Vitreous biopsy & Negative & 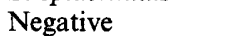 & - & + & - & + \\
\hline 15 & $\mathrm{~L}$ & Vitrectomy & Negative & Negative & - & + & - & + \\
\hline 16 & $\mathbf{R}$ & Vitreous biopsy & $\begin{array}{l}\text { Pleomorphic } \\
\text { positive rods }\end{array}$ & P. acnes & + & + & - & + \\
\hline 16 & $\mathbf{R}$ & Vitrectomy & Negative & P. acnes & + & + & + & + \\
\hline 17 & $\mathrm{~L}$ & Vitreous biopsy & Negative & Negative & - & - & - & - \\
\hline 18 & $\mathrm{~L}$ & Vitrectomy & Negative & Negative & - & + & - & - \\
\hline 18 & $\mathrm{~L}$ & Capsule biopsy & Negative & Negative & + & + & - & - \\
\hline 19 & $\mathbf{L}$ & Vitrectomy & $\begin{array}{l}\text { Pleomorphic } \\
\text { positive rods }\end{array}$ & Negative & - & + & - & + \\
\hline
\end{tabular}

$\overline{\text { EUP, external universal primers; IUP, internal universal primers; EPAP, external } P \text {. acnes }}$ primers; IPAP, internal P. acnes primers; R, right eye; L, left eye.

mitted detection of $1 \mathrm{pg}$ of $P$. acnes DNA in TE buffer and in normal vitreous. With nested PCR (Pal and rPa2) for a further 25 cycles, $10 \mathrm{fg}$ of $P$. acnes DNA in $\mathrm{TE}$ buffer and in normal vitreous was detected.

\section{XhoI restriction endonuclease digest}

Xhol restriction endonuclease digest of the 160-bp nested PCR production of $P$. acnes produced a $135-\mathrm{bp}$ 
and a 25-bp product. The A. israelii nested PCR product was not cleaved by the enzyme.

\section{Clinical specimens}

Of 29 control vitreous samples, four gave positive results after nested PCR with universal primers, but none was positive after nested PCR with $P$. acnes primers. In all cases, conventional microbial culture of vitreous specimens was negative. Of 23 vitreous samples from 19 patients with delayed post-operative endophthalmitis, 17 gave positive results with nested universal primers, and eight with nested $P$. acnes primers (table IV). No sample positive by conventional microbial culture gave negative results by PCR either with universal or $P$. acnes primers. All four samples from which $P$. acnes was isolated clinically gave positive results by PCR, as did a case in which $P$. acnes was suspected on clinical grounds and seen on Gram's stain but which was culture negative. In addition to this, three further cases in which the clinical diagnosis of $P$. acnes delayed post-operative endophthalmitis was suspected, but culture for the organism was negative, were PCR positive. S. epidermidis was cultured from one of these cases. Nine vitreous specimens that gave positive results with the universal primers gave negative results by PCR with $P$. acnes primers; of these, four were culture positive (table IV; S. epidermidis 2, Citrobacter freundii 1, Streptococcus group D 1).

\section{Discussion}

This study was designed to answer two specific clinical questions. First, whether PCR could be employed to identify low grade infections in vitreous samples with universal primers or primers specific for $P$. acnes. Second, whether the detection by PCR of cases of $P$. acnes endophthalmitis which are negative by culture would help to indicate the true incidence of low grade bacterial endophthalmitis. At present, cases are seen in which persistent recurring low grade inflammation is present after surgery that could be of bacterial origin, but this is not confirmed by conventional microbiological techniques. Scanning electronmicroscopy of intra-ocular lenses explanted from such cases has demonstrated bacteria adherent to the implant optic and haptics of such cases. ${ }^{23}$ Furthermore, it is possible that bacteria as yet unrecognised as intra-ocular pathogens are present in some of these cases. DNA sequencing of the universal nested PCR product may allow identification of the causative organism in a number of such cases.

Universal primers were chosen from 16S rDNA because of the large amount of available sequence information ${ }^{32-34}$ and because highly conserved regions of the gene allow for synthesis of primers that amplify a wide spectrum of bacteria. ${ }^{29}$ Successful amplification of DNA from all bacteria implicated in delayed and acute post-operative endophthalmitis was obtained with these primers, confirming the high homology between the universal primers and all bacterial 16S rDNA template sequences.

16S rDNA was chosen as the target gene for $P$. acnes primers because it is the only published sequence for this organism. Over $97 \%$ sequence homology between the 16S rDNA of $P$. acnes and $A$. israelii, a rare cause of delayed post-operative endophthalmitis, meant that it was not possible to construct primers completely specific to $P$. acnes, even from areas of low sequence homology within the gene (variable regions V1-V6). However, the base-pair difference between $P$. acnes and $A$. israelii in the nested (2nd round) product (E. coli position 93) lies in the recognition site for restriction endonuclease $\mathrm{XhoI}$, permitting differentiation of the two bacterial sequences. Of the other organisms causing delayed post-operative endophthalmitis, significant differences between the $P$. acnes primers and $16 \mathrm{~S}$ rDNA templates were present in all cases except between rPA2 and the V2 region of $A$. viscosus, with only two mismatches and two deletions. Despite the apparent low number of primer-template mismatches in this instance, no non-specific amplification occurred in the nested PCR with an annealing temperature of $62^{\circ} \mathrm{C}$.

As neither the universal nor $P$. acnes primers amplified human nuclear DNA, and human mitochondrial DNA has no sequence homology to primer G1, a false positive result from non-specific amplification of human DNA was not expected.

The sensitivity of the universal primers was such that $50 \mathrm{fg}$-approximately 10 genome copies - of $S$. epidermidis DNA could be detected in vitreous. This approximates to the sensitivity achieved in other studies and supports the belief that PCR is not inhibited by vitreous humour in a template sample. ${ }^{35}$ The sensitivity of the P. acnes nested PCR was fivefold more than PCR with the universal primers.

Preparation of clinical vitreous samples for PCR by boiling, ${ }^{36}$ treatment with $0 \cdot 1 \mathrm{M} \mathrm{NaOH}^{37}$ and proteinase $\mathrm{K}$ extraction followed by phenol: chloroform extraction and ethanol precipitation was unsuccessful. This was thought to be due to the recalcitrant nature of organisms such as Propionibacterium spp. and Actinomyces spp.$^{38}$ with these methods of preparation. The Mini-Beadbeater ${ }^{\sqrt{m}}$ was employed to lyse bacterial cells suspended in phosphate-buffered saline and was followed by successful PCR amplification of the lysed sample. The Mini-Beadbeater has been used previously for quick and effective DNA extraction for taxonomic purposes ${ }^{28}$ but has not been described previously in a clinical application.

In none of 29 control cases that underwent vitrectomy had previously surgery been performed. There is no evidence that normal vitreous contains bacterial DNA - this implies that the four positive results with universal primers represent pick-up of bacteria from the ocular surface at the time of vitreous sampling. This positivity rate or $14 \%$ in clinically non-infected cases is higher than in studies of PCR in meningococcal 
meningitis ${ }^{39}$ and acute retinal necrosis ${ }^{35}$ and probably reflects an increased risk of positive results with universal primers. Spiking of all negative samples with $P$. acnes DNA confirmed that positive results were obtainable in all cases, despite the fact that vitreous samples contained blood in four cases. The fact that a positive result was possible in all 29 cases after spiking with $P$. acnes DNA suggests that bacteria other than $P$. acnes in the conjunctival $\mathrm{sac}^{40,41}$ may have been responsible for the four positive results with the universal primers in the non-infected group, despite the fact that this organism is frequently isolated from lid cultures. ${ }^{42}$

The patients in the delayed post-operative endophthalmitis group were selected on the basis of low grade inflammation occurring at least 1 month after surgery. Not every case had all the typical clinical characteristics of $P$. acnes endophthalmitis, but it was felt that this was the most appropriate group in which to look for the organism. Positive PCR results with universal primers corresponded to cases that were positive by Gram's stain or bacterial culture, or both; no culture positive case gave negative PCR results with universal primers. Within this group, cases culture positive for $P$. acnes gave positive PCR results. One case had a Gram's stain consistent with $P$. acnes, was culture negative but PCR positive, and three further culture negative cases were PCR positive. In one of these cases, $S$. epidermidis was cultured - suggesting that $P$. acnes may have been present as part of a mixed infection. It appears that the PCR is capable of detecting $P$. acnes in certain cases of delayed postoperative endophthalmitis in which the organism is not detected by other means. Larger numbers of samples are required to test these preliminary findings further.

The localised nature of $P$. acnes endophthalmitis around the capsular bag suggests that vitreous sam-

\section{References}

1. Fisch A, Salvanet A, Prazuck T, et al. Epidemiology of infective endophthalmitis in France. Lancet 1991; 338: 1373-1376.

2. Rowsey JJ, Newsom DL, Sexton DJ, Harms WK. Endophthalmitis: current approaches. Ophthalmology 1982; 89: 1055-1066.

3. Puliafito CA, Baker AS, Haaf J, Foster CS. Infectious endophthalmitis. Review of 36 cases. Ophthalmology 1982; 89: $921-929$

4. Irvine WD, Flynn HW, Miller D, Pflugfelder SC. Endophthalmitis caused by gram-negative organisms. Arch Ophthalmol 1992; 110: 1450-1454.

5. Ormerod LD, Paton BG, Haaf JS, Topping TM, Baker AS. Anaerobic bacterial endophthalmitis. Ophthalmology 1987; 94: 799-808.

6. Driebe WT, Mandelbaum S, Forster RK, Culbertson WW. Pseudophakic endophthalmitis. Diagnosis and management. Ophthalmology 1986; 93: 442-446.

7. Verbraeken $H$, Rysselaere M. Bacteriological study of 92 cases of proven infectious endophthalmitis treated with pars plana vitrectomy. Ophthalmologica 1991; 203 : 17-23.

8. Weber DJ, Hoffman KL, Thoft RA, Baker AS. Endophthalmitis following intraocular lens implantation: report of the 30 cases and review of the literature. Rev Infect Dis 1986; 8: 12-20.

9. Friedman E, Peyman GA, May DR. Endophthalmitis caused pling may fail to detect the organism. This theory does not appear to have been supported by the data presented here, a minute number of organisms present in the vitreous biopsy being sufficient for a positive PCR result. Capsule biopsy and fluid from the capsular bag are now routinely taken in these cases to minimise sampling error.

Identification of $P$. acnes by PCR in cases which were culture negative did not alter immediate management. However, it prevented subsequent persistence with systemic steroids in one case, with earlier recourse to further surgery. In cases in which vitrectomy is performed initially and intravitreal antibiotics given, but in which conventional cultures are negative, a positive PCR result in the face of further inflammation in the capsular bag may result in earlier further surgical intervention. Mild intra-ocular inflammation managed with a vitreous tap and intravitreal antibiotics with negative cultures but a positive PCR result may make the clinician less likely to persist with topical and oral steroids and consider early surgery.

Although numbers in this study were small, PCR amplification with $P$. acnes primers followed by $X h o I$ restriction endonuclease digest is a sensitive way of detecting minute quantities of $P$. acnes in vitreous and may alter clinical management of some cases. The positive results with universal primers amongst control cases require further evaluations. However, the universal primers provide a useful starting point for the detection of bacterial DNA from otherwise undiagnosed cases of endophthalmitis. Cloning and sequencing of the $16 \mathrm{~S}$ rDNA PCR products from these cases may permit identification of the pathogen involved.

We acknowledge the expert advice received from Dr R. A. Cox, National Institute for Medical Research, Mill Hill and Mr J. K. G. Dart, Moorfields Eye Hospital, London, in the preparation of this manuscript.

by Propionibacterium acnes. Can J Ophthalmol 1978; 13: 50-52.

10. Jaffe GJ, Whitcher JP, Biswell, R, Irvine AR. Propionibacterium acnes endophthalmitis seven months after extracapsular extraction and intraocular lens implantation. Ophthalmic Surg 1986; 17: 791-793.

11. Meisler DM, Mandelbaum S. Propionibacterium-associated endophthalmitis after extracapsular cataract extraction. Review of reported cases. Ophthalmology 1989; 96: 54-61.

12. Meisler DM, Palestine AG, Vastine DW et al. Chronic propionibacterium endophthalmitis after extracapsular cataract extraction and intraocular lens implantation. $\mathrm{Am}$ J Ophthalmol 1986; 102: 733-739.

13. Meisler DM, Zakov ZN, Bruner WE et al. Endophthalmitis associated with sequestered intraocular propionibacterium acnes. Am J Ophthalmol 1987; 104: 428-429.

14. Roussel TJ, Culbertson WW, Jaffe NS. Chronic postoperative endophthalmitis associated with Propionibacterium acnes. Arch Ophthalmol 105: 119-1201.

15. Vafidis GC. Propionibacterium acnes endophthalmitis. $\mathrm{Br} J$ Ophthalmol 1991; 75 : 706.

16. Zambrano W, Flynn HW, Pflugfelder SC et al. Management options for Propionibacterium acnes endophthalmitis. $O p h$ thalmology 1989; 96: 1100-1105.

17. Fox GM, Joondeph BC, Flynn HW, Pflugfelder SC, Roussel TJ. Delayed-onset pseudophakic endophthalmitis. $A m J$ Ophthalmol 1991; 111: 163-173.

18. Walker J, Dangel ME, Makley TA, Opremcak EM. Post- 
operative Propionibacterium granulosum endophthalmitis. Arch Ophthalmol 1990; 108: 1073-1074.

19. Davis JL, Koidou-Tsiligianni, A, Pflugfelder SC, Miller D, Flynn HW, Forster RK. Coagulase-negative staphylococcal endophthalmitis. Increase in antimicrobial resistance. Ophthalmology 1988; 95: 1404-i410.

20. Jansen B, Hartmann C, Schumacher-Perdreau F, Peters G. Late onset endophthalmitis associated with an intraocular lens: a case of molecularly proven Staphylococcus epidermidis aetiology. Br J Ophth 1991; 75 : 440-441.

21. Roussel TJ, Olson R, Rice T, Meisler D, Hall G, Miller D. Chronic postoperative endophthalmitis associated with Actinomyces species. Arch Ophthalmol 1991; 109: 60-62.

22. McManaway JW, Weinberg RS, Coudron PE. Coryneform endophthalmitis: two case reports. Arch Ophthalmol 1990; 108: $942-994$.

23. Cusumano A, Busin M, Spitznas M. Is chronic intraocular inflammation after lens implantation of bacterial origin? Ophthalmology 1991; 98: 1703-1710.

24. Weisburg WG, Barnes SM, Pelletier DA, Lane DJ. 16S ribosomal DNA amplification for phylogenetic study. $J$ Bacteriol 1991; 173: 697-703.

25. Pallen M, Butcher PD. New strategies in microbiological diagnosis. J Hosp Infect 1991; 18 Suppl: 147-158.

26. Chen K, Neimark H, Rumore P, Steinman CR. Broad range DNA probes for detecting and amplifying eubacterial nucleic acids. FEMS Microbiol Lett 1989; 57: 19-24.

27. Grimont F, Grimont PAD. DNA fingerprinting analysis. In: Stackebrandt E, Goodfellow M (eds) Nucleic acid techniques in bacterial systematics. Chichester, J. Wiley and Sons. $1991 ; 252-256$.

28. Gutell RR, Wieser B, Woese CR, Noller HF. Comparative anatomy of 16S like ribosomal RNA. Prog Nucleic Acid Res 1985 ; 32: 155-216.

29. Woese CR, Gutell R, Gupta R, Noller HF. Detailed analysis of the higher-order structure of $16 \mathrm{~S}$-like ribosomal ribonucleic acids. Microbiol Rev 1983; 47: 621-669.

30. Higgins DG, Sharp PM. Clustal: a package for performing multiple sequence alignment on microcomputer. Gene 1988; 73: 237-244.

31. Bottger E. Frequent contamination of TAQ polymerase with DNA. Clin Chem 1990; 36: 1258-9.

32. Olsen, GJ, Larsen N, Woese CR. The ribosomal RNA database project. Nucleic Acids Res 1991; 19: 2017-2021.

33. Neefs JM, Van de Peer Y, De Rijk P, Goris A, De Wachter R. Compilation of small ribosomal subunit RNA sequences. Nucleic Acids Res 1991; 19 Suppl: 1987-2015.

34. De Rijk P, Neefs J-M, Van de Peer Y, de Wachter R. Compilation of small ribosomal subunit RNA sequences. Nucleic Acids Res 1992; 20 Suppl: 2075-2089.

35. Nishi M, Hanashiro R, Mori S, Masuda K, Mochizuki M, Hondo R. Polymerase chain reaction for the detection of the Varicella-Zoster genome in ocular samples from patients with Acute Retinal Necrosis. Am J Ophthalmol 1991; 114: 603-609.

36. Jackson DP, Hayden JD, Quirke P. Extraction of nucleic acid from fresh and archival material. In: McPherson MJ, Quirke P, Taylor GR (eds) PCR: a practical approach. Oxford, IRL Press. 1991: 29-50.

37. Beji A, Izard D, Gavini F, Lederc H, Leseine-Delstanche $M$, Krembel J. A rapid chemical procedure for isolation and purification of chromosomal DNA from gram negative bacilli. Anal Biochem 1987; 162: 18-23.

38. Johnson JL. Isolation and purification of nucleic acids. 1991. In: Stackebrandt E, Goodfellow M. (eds) Nucleic acid techniques in bacterial systematics. Chichester, J. Wiley and Sons. 1991: 1-19.

39. Ni H, Knight AI, Cartwright, K, Palmer WH, McFadden J. Polymerase chain reaction for diagnosis of meningococcal meningitis. Lancet 1992; 340: 1432-1434.

40. Perkins RE, Kundsin RB, Pratt MV, Abrahamsen I, Leibowitz HM. Bacteriology of normal and infected conjunctiva. J Clin Micro 1975; 1: 147-149.

41. Matuura $H$. Anaerobes in the bacterial flora of the conjunctival sac. Jpn J Ophthalmol 1971; 15: 116-124.

42. McNatt J, Allen SD, Wilson LA, Dowell VR. Anaerobic flora of the normal human conjunctival sac. Arch Ophthalmol $1978 ; 96: 1448-1450$. 